\title{
Comparative Analysis of the Hybrid Tactics Application by the Russian Federation in Conflicts with Georgia and Ukraine
}

Lesia Dorosh, Olha Ivasechko, Jaryna Turchyn

The essence and main characteristics of the hybrid war are reviewed as a means of destroying the enemy country from inside due to the effective combination of conventional armed forces, subversion, propaganda, and dissemination of misinformation. The hybrid tactics used by the Russian Federation in Ukraine and Georgia are investigated. A comparativeanalysisof the military component in the confrontation between Russia, Ukraine and Georgia is conducted, the peculiarities of informational and psychological confrontation and factors that led to the significant achievements of the Russian side in the hybrid warfare are revealed, economic aspect of the hybrid confrontation are clarified (especially regarding the factors of financial, energy and raw material dependence) and, finally, the key conditions for the widespread use of hybrid methods of confrontation during modern armed conflicts are identified. Thedifference is proved between conflicts in Georgia and Ukraine, mainly in the use of military means. It is established that the conditions for the conflict in Crimea were unique, or at least extremely rare, and they can hardly be reproduced in any other place. It is noted that in the future, hybrid war will become rather a situational phenomenon, because the implementation of aggressive actions

Lesia Dorosh, Olha Ivasechko, Jaryna Turchyn. Comparative Analysis of the Hybrid Tactics Application by the Russian Federation in Conflicts with Georgia and Ukraine. Central European Journal of International and Security Studies I3, no. 2 : $48-73$.

(C) 2019 CEJISS. Article is distributed under Open Access licence: Attribution NonCommercial 3.0 Unported (cc by-nc 3.0). 
against another state without the necessary conditions for it will lead either to a quick defeat of the aggressor state, or will force such a state to move toconventional warfare, which requires significant financial costs and inevitably will cause decline in the prestige of such a state within the international community.

Lesia Dorosh

Olha Ivasechko

Keywords: hybrid war, conflict in the East of Ukraine, Five Days War, Jaryna Turchyn Georgia, the Russian Federation

\section{The Relevance of Scientific Research}

The armed aggression of the Russian Federation against Ukraine with the widespread applicationof hybrid tactics brokeout in February of20I4 with the annexation of theCrimean peninsula andmade the world rethink the established norms and tactics of war.According to OstapKushnir,today it is about the manifestations of Cold War discourse when Western states, facing the first case of a massive violation of sovereignty in the new millennium in Europe, imposed sanctions to stop the aggressive behaviour of Russia ${ }^{\mathrm{I}}$.

The policy of Russia, connected with the violent seizure of new territories, proves its desire to change the current world order and readinessfor further aggression on the international arena. It is about a new foreign policy concept of Russia, which, according to Zbigniew Brzezinski, contains the following components: I) 'separated people'; 2) 'the protection of compatriots abroad'; 3)'Russian world' ('Ruskiymir'); and 4) the importance of recognition and support, coverage and promotion of 'the great Russian civilization' ${ }^{\prime 2}$. OstapKushnir notes that Russian commitment to achieving favourable results is so significant that Putin is ready to challenge the global balance of power, openly attacking the US and Western powers, and providing military assistance to the third parties and even putting the welfare of Russian citizens at risk 3 . Following the annexation of Crimea, Russian president Vladimir Putin declaredthat he was ready to bring his country's nuclear forces into a state of combat readiness, in case of an intervention by the United States and its allies ${ }^{4}$.

Obviously, a search for the ways to counter new hybrid threats that have arisen in connection with the current international position of Russia is relevant not only for Ukraine.ltis also about Moldova, Poland, Lithuania, Latvia, Estonia and other countries that the Russian Federation historically relates to its own sphere of influence and is 
actively trying to recover today. Rod Thornton assumes that Western states must adapt to the situation when they are in a 'constant' situation of hybrid war with Russia, which today has become a habitual affair of international politics, acquiring characteristics that can ful-

CEJISS ly embrace the goals and methods used by Russias. These include the

2/20I9 Russian model of the hybrid war, covering Russian investments into the main sectors of European economies and Russian links to organized crime with local criminal elements ${ }^{6}$. In order to identify the most accurate characteristics of hybrid tactics used by the Russian Federation in its foreign policy, it is also important to reveal the content of its previously implemented'Georgian scenario'. After comparing Russia's actions in the 'Five Day War' of 2008 in Georgia and the RussianUkrainianongoing conflict (started in 2014), it will be possible to trace the evolution of the hybrid tactics of the Russian Federation, assess the effectiveness of the widespread use of non-military countermeasures, and to work out effective ways of counteracting.

\section{The Theoretical Basis of the Study}

Nowadays, to indicate modern types of wars, a variety of terminology is used: hybrid war, asymmetric confrontation, nontraditional, nonlinear warfare, a war of the new generation, a war of the 4 th and 5th generations, the grey war, etc. At the same time, researchers point out that the hybrid war is a Western term, not Russian, simultaneously they make use of the article named 'The Value of Science in Prediction' written by Valery Gerasimov, General of the Russian Armed Forces (2013).? Although Valery Gerasimov does not use the term explicitly, he is considered to be the author of the Russian Federation hybrid war concept in its present form. The author has repeatedly emphasized the importance of using the protest potential of the local population in conditions of armed confrontation with the enemy, as well as the use of non-military instruments (political, economic, informational, humanitarian, etc.). As Stephen Dayspring notes, Gerasimov even established a ratio of 4:I between non-military and military means to underline the lesser role of military force in his model. ${ }^{8}$

Valery Gerasimov emphasised the importance of raising social dissatisfaction in the targeted state, undermining the authority of local establishments, relaxation of military capabilities of the enemy and creating a vacuum of power. This can be achieved, in particular, by manipulating information and special operations in cyberspace. The 
armed forces (mainly the forces of special operations) - under the influence of peacekeeping forces or crisis response forces - must arrive at the final stage of the conflict to ensure success ${ }^{9}$. Gerasimov believes that such methods are more meaningful to achieving strategic goals than military means, since they can reduce the enemy's combat potential, creating social upheavals and helping to collapse the situation without overt use of violence.

The actions of Russia in Ukraine in 2014 have intensified interest in the concept of hybrid war. For many Western commentators, this term turned out to be the best way to describe the variety and mix of tools and methods used by the Russian Federation during annexation in theCrimea and support provided to separatist groups in Eastern Ukraine $^{\text {Io }}$. Western countries realized the existence of a new type of threat, which combines a number of different types of confrontation - from military actions (conventional, irregular forces and Special Forces) to economic, informational and cybercrime, including acts of terrorism and criminal activity as well as support provision and sponsorship of political protestsand an intensive disinformation campaign $^{\text {II }}$.This led to a significant popularization of hybrid war research conduct among scholars from the West, as well as among Ukrainian scholars, primarily research that concerns the conflict in the Crimea and events in Eastern Ukraine since $20 \mathrm{I} 4$.

Currently, there are two main academic approaches in the process of hybrid wars study ${ }^{12}$. The first is represented by researchers (Williamson Murray, Peter R. Mansoor ${ }^{\mathrm{r}}$ ) who consider the hybrid war to be a useful, but not new concept. The researchers offer numerous examples of hybrid methods and approaches at the tactical, operational, and strategic levels that were used in the days of the Peloponnesian War and related to the works of Chinese philosopher Sun Tzu in the 5 th century BC ${ }^{14}$, recall the Thirty Years War and the Vietnam War, the Napoleonic campaign and both World Wars, in which regular and irregular elements were combined. ${ }^{15}$ So, the essence of the hybrid war is defined asthe possibility of a combined use of regular and irregular (militias, partisans, militants and terrorists) forces on the battlefield. ${ }^{16}$ The United Countries Army Training and Doctrine Command has expanded the list of participants which can be attributed to irregular forces. Thus, in a hybrid confrontation, military forces, national paramilitary forces (such as internal security forces, police and border guards), insurgent organizations (armed movements whose main activity is subversion 
and violence in order to change the existing status quo), partisan groups (irregular forces that include local people and operate in the occupied territory) as well as criminal organizations (such as gangs, drug cartels or hackers) with parallel widespread operations in cyberspace. ${ }^{17}$

CEJISS Although such a vision of hybrid war as a simple combination of 2/20I9 conventional and irregular forces is widespread, it does not explain the new role of non-military means in achieving those political goals that were previously achieved exclusively by military force. So, Joseph Schroefland Stuart Kaufman criticize this direction, arguing that its supporters are trying to simplify the concept of hybridity, pointing to an example that is defined as a mixture of conventional and irregular battles $^{18}$. Also, the representatives of this direction do not pay adequate attention to revising necessary prerequisites for the successful holding of hidden operations, effective support provision to criminal groups or cyber attacks. ${ }^{19}$

Theorists of the second approach (Timothy McCulloh, Richard Johnson $^{20}$, Jack $\mathrm{McCuen}^{21}$ ) interpret the hybrid war as a relatively new phenomenon. Like their opponents, they also reveal its meaning as a combination of conventional and irregular forces during war, but at the same time recognize the growing importance of subversion, the new role of the use of modern technology to limit the enemy's military strength and its overall ability to resist external interference. Here the possibility of destabilizing the enemy country using economic levers of influence and measures in the information field is justified. Therefore, the proposed inquiry is essentially based on this approach in the study of hybrid war and hybrid tactics, which will allowus to fully explore and analyze it as a complex phenomenon through its aspects such as economic and informational (psychological) confrontation, cyberwar, and military operations.

The concept of 'hybrid war' came into use in Western scientific thought in the mid-2ooos to denote the combination of traditional and non-traditional ('grey') threats to the Western countries. This idea was later developed by Frank Hoffman, an American researcher who identified the application of closely integrated traditional (army) and non-traditional (militants, rebels, terrorists) armed formations as the main feature of the hybrid war. ${ }^{22}$ His article Conflict in the 2Ist Century: The Rise of Hybrid Wars, published in 2007, is considered to be a fundamental work in the inquiry. The author argues that conventional and unconventional combat tactics have been used throughout world 
history, but also points to the fact that modern technologies have changed the nature of the war and the threats that are derived from it. ${ }^{23}$ Like in Hybrid Warfare and Challenges (2009), Frank Hoffman observes that the war is transformed into a new hybrid form, where opponents are trying to use absolutely all available means of warfare, and 'the lethality of the intercountry conflict is complemented by fanaticism and high emotionality of irregular military formations. ${ }^{24} \mathrm{Much}$ of the research concerns the actual hybrid tactics of the Russian Federation and their use in relations with Georgia or Ukraine. An authoritative researcher of the hybrid war topic is Peter Pomerantsev, who, together with Michael Weis in their work The Menace of Unreality: How the Kremlin Weaponizes Information, Culture and Money, examine the policies of the Russian President Vladimir Putin, and the tools used by him to implement hybrid influence on foreign countries; the authors determine the vulnerability of the Western countries regarding the Russian Federation activities, and provide a wide range of recommendations against the hybrid effects of Russia ${ }^{25}$.The work of Keir Giles ${ }^{26}$ called Russia and Its Neighbours: Old Attitudes, New Capabilities is dedicated to the study of aggressive actions of the Russian Federation in cyberspace. The reasons why the Russian Federation is resorting to aggressive actions against the countries that were formerly part of the USSR are analyzed; the activities of Russia in cyberspace are investigated, and its further actions within the international arena are predicted. A detailed analysis of the Russian Federation's attack on the cyberspace of Georgia during the 'Five Days War' was carried out by David M. Hollis (Cyberwar Case Study: Georgia 2008), who looks not only at the goals and tools of cyberattacks, but also provides recommendations for strengthening the protection of cyberspace from external attacks. ${ }^{27}$

A thorough investigation of the essence of the hybrid war, as well as examples of its wage in Georgia and Ukraine, was carried out by a group of Czech authors, namely Zdeněk Kříž, Peter Števkov and Zinaida Shevchuk. In their work, named Hybrid Warfare: A New Phenomenon in Europe's Security Environment, the application of Russian hybrid confrontation methods was analyzed, and ways to increase a country's abilities to withstand hybrid influences are provided. ${ }^{28}$ Subversive activity is the basic idea of the concept of hybrid war according to the Czech scholars, which consists of four stages: I) demoralization; 2) destabilization; 3) artificial creation of a crisis situation; and
Lesia Dorosh

Olha Ivasechko

Jaryna Turchyn 
4) establishment of control over the enemy's community by means of internal forces acting on the side of the aggressor. ${ }^{29}$

Yana Gumen uses the example of the annexation of the Crimea and the conflict in the East of Ukraine to explore the role of mass media in

CEJISS shaping public opinion about the events ${ }^{30}$. Taras Kuzio distinguishes 2/20I9 the key factors that led to the transition of Ukraine from a state in peace to a state in the conflict in the Donbas and with Russia ${ }^{35}$.

A detailed analysis of the wars conducted by Russia, as well as their comparison with other recent conflicts, was carried by Marcel H. Van Herpen $^{32}$, and a more recent article in the New Yorker analyzes the various aspects of the hydride confrontation between Russia and the West ${ }^{33}$. A thorough analysis of Russia's defence industry and its functions in the public sphere was carried out by JolantaDarczewska as an interplay of the defence sphere with the spheres of ideology, educationand information space that manifests itself in attempts to prevent a wave of color revolutions, challenge the NATO hegemony in the information space, and protect the Russian language status and Russian-speaking people in the neighbouring countries, as well as Russia's national interests outside of Russia's territory ${ }^{34}$.

The work of Volodymyr Horbulin is singled out among the Ukrainian scholars who study components of the hybrid war of the Russian model. In his article, titledBlack Hole: an Endless Deadlock of Settlement, the author defines the number of economic losses suffered by the Russian Federation due to its military aggression in Eastern Ukraine. ${ }^{35}$ No less well known is another work of the researcher, named Hybrid War: It's Just the Beginning, which details knowledge about the application of hybrid tactics of the Russian Federation in Syria and Ukraine, as well as Russia's attempts to study the informational influence on the EU countries. ${ }^{36}$ A slightly different definition of the hybrid war is proposed by Yu. Romanchyshyna, who describes this phenomenon as 'cooperation (of the state) with mercenaries and local criminals who are trained, armed and funded to carry out 'work' that would otherwise be carried out by the military. ${ }^{37}$ The researcher notes that modern hybrid war combines confrontation in various spheres, in particular in cyberspace, economics and diplomacy, and also allows the aggressor to separate itself from conflict and achieve strategic goals without direct military incursions. In the context of the theme, it is worthwhile to highlight the works of P. Shevchuk, named Informational and Psychological War of Russia against Ukraine: How to Counteract 
$i t^{38}$, and Yevhen Magda's work Hybrid War: To Survive and to Win. ${ }^{39}$ They are oriented towards the practical components of counteraction against Russian hybrid influences, and their conclusions can be used in the development of an appropriate country policy aimed at levelling the hybrid tactics of the aggressor country.

Obviously, the studies of hybrid wars represented by researchers from the Western countries and Ukraine, by their goals and content, differ significantly from the achievements of the Russian Federation scientists. Thus, recent studies published in the Western states and Ukraine are mainly devoted to the revision of new hybrid threats caused by the actions of the Russian Federation and the ways to counter them. In contrast, Russian scientists are more concerned with theconsequences of the 'colour' revolutions and the Arab Spring; they put emphasis on the dominant role of the United States and develop recommendations for strengthening Russia's military potential.

Thus, in our study, we adhere to the definition that hybrid warfare involves 'the application of military and non-military tools in an integrated campaign to achieve surprise, seize the initiative and obtain both a psychological and physical advantage through the use of diplomatic means, specific presentation of information (disinformation), use of cyber-attacks, hidden and sometimes open military and intelligence actions, and economic pressure..$^{\circ}$

Thus, we can conclude that, despite the variety of interpretations of the 'hybrid war' concept, scholars agree that hybrid conflicts are characterized by hidden use of force (symmetrical and asymmetric methods of combat operations), with simultaneous widespread application of non-military means that affect the consciousness of people. According to Ralph D. Thiele, only when non-military methods are coordinated or integrated with the real threat or use of armed force, politicians must describe international political rivalry as a form of hybrid warfare ${ }^{41}$.

The purpose of the hybrid war is to destroy the enemy's country from inside by manipulating the consciousness of the citizens of this country, which is achieved due to subversion and propaganda, dissemination of misinformation and other methods of psychological influence. At the same time, hybrid tactics are not the invention of the Russian Federation and have already been used in the past, by the Soviet Union in particular. However, the current level of information technology development and the extent of their penetration into all
Hybrid Tactics

of the Russian

Federation 
spheres of life of the modern human community have led to a significant increase in the danger of the use of hybrid tactics by modern countries to achieve their foreign policy goals. According to Mark Galeotti, the role of non-military means to achieve political and strategic goals

CEJISS has increased, and, in many cases, they have exceeded the strength of 2/20I9 weapons in their effectiveness ${ }^{42}$.

So, the purpose of this article is to analyze and track the evolution and study of the effectiveness of the hybrid tactics of the Russian Federation in the 'Five Day War' in 2008 in Georgia and in the ongoing Russian-Ukrainian conflict in military, economic and information spheres, as well as in cyberspace. To accomplish this task, several steps have been undertaken: primarily, the military component has been analyzed and compared in the confrontation between Russia and Ukraine and Georgia; secondly, the peculiarities of the informational and psychological confrontation and factors that led to significant achievements of the Russian side in the hybrid war have been identified; thirdly, the economic aspect of the hybrid confrontation has been clarified, especially in relation to the factors of financial, energy and raw materials dependence; and, finally, the key conditions have been identified for further widespread use of hybrid methods of confrontation during an armed conflict at the present stage.

\section{Military-Strategic Actions of the Russian Federation in Georgia and Ukraine in the Context of Conducting Hybrid Wars}

Military actions during the hybrid war are carried out secretly and aimed at subversion. It is known that Russia does not apply direct tactics of military intervention; its strategy in recent conflicts is more complex and well thoughtout. It is about the use of trained Special Forces instead of non-regular forces in similar military operations. Such military operations are carried out not by regular troops, but by specially trained irregular troops. Such military units are created in order to distract the enemy's attention from external problems through subversion within the country, loosening its political system, destabilizing the political situation, involving third parties, and the local population of the attacked state. Moreover, Special Forces are capable of creating, organizing and training paramilitary detachments inside the enemy state, as well as managing them. ${ }^{43}$ According to Valery 
Gerasimov, the forces of special operations and internal opposition should be used to create a permanent front throughout the enemy's territory in conjunction with information confrontation. ${ }^{44}$

From a military position, the situation in Ukraine is particularly interesting due to the events that took place in the Crimea (second half of February - first half of March 20I4). A foreign military without recognition signs on their uniforms, weapons and equipment (but with the weapons of the Russian Army) captured the key political objects of the Autonomous Republic of the Crimea. The capture took place quickly, and in most cases, strategic objects were conquered without a single shot. ${ }^{45}$ Moreover, the fact that the attackers did not wear any distinguishing marks or were dressed in civilian clothing has led to a significant limitation of the ability of the Ukrainian authorities to apply force against them. ${ }^{6}$ However, there were many indicators of involvement with regular and well-trained Russian troops.

The political, cultural and social situation in the Crimea that existed in early 2014 was extremely favourable for the application of hybrid war tactics. In order to seize the Crimean Peninsula, the Russian Federation successfully used the pro-Russian mood of the local population, which made it possible to nullify the efforts of official Kyiv to rectify the situation.

Despite the fact that the Russian Federation was able to annex the Crimean peninsula without encountering significant resistance from the Ukrainian side, the actions of the Russian military and pro-Russian forces in the east of Ukraine in 2014 quickly grew into widespread battles with the Ukrainian armed forces, as the Ukrainian government launched an'anti-terrorist operation' against the Russian military invasion of Donbas. ${ }^{47}$ The first successes of the Ukrainian armed forces in late June and early July 2014 forced the Russian military to open artillery fire from the Russian territory on the advancing Ukrainian forces. In mid-August 20I4 Russia was forced to bring manyof its troops into the territory of Ukraine.

The number of Russian troops in Ukranian territory has been constantly changing. As of the end of August 2014, there were 6,000-6,500 Russian servicemen in the east of Ukraine. The largest number of Russian troops that were simultaneously present in Donbas reached approximately I0,000 people in December 2014. The Ministry of Defense of the Russian Federation was forced to engage II7 military units and combat armies in the military operation against Ukraine, of
Lesia Dorosh

Olha Ivasechko

Jaryna Turchyn 
which 42,00o were at the border with Ukraine, opened artillery fire on Ukrainian troops or directly participated in hostilities in Donbas. ${ }^{48}$ The hybrid war of the Russian Federation in the east of Ukraine, conducted in accordance with the doctrine of ValeryGerasimov, suffered, unlike

CEJISS the Crimean version, a quick defeat, in particular in connection with 2/20I9 the impossibility of confronting a large-scale military operation of the Ukrainian Army ${ }^{49}$ Hence, in the East of Ukraine, Russia began an open invasion using the latest types of weapons and military equipment in the war that continues today. However, separatists and the Russian government continue to blame Kyiv for violating the ceasefire regime (Minsk agreements) to justify further attacks ${ }^{50}$.

Military operations on the territory of Georgia in 2008, which were open and not masked by the large-scale offensive of the Russian armed forces, significantly differed from the above events. The overall goal of the military operation in Georgia was aimed at establishing full control over Abkhazia and South Ossetia, creating there large Russian military bases and restoring the Russian presence on the Georgian territory, which existed before the withdrawal of Russian armed forces from Georgia after the collapse of the Soviet Union. VitaliyShlikov characterizes this war as 'an armed conflict of low intensity with the application of only conventional weapons and entirely traditional tactical techniques, during which no major battles took place. ${ }^{51}$ The exact number of united forces of the Russian, Abkhazian and South Ossetian sides involved in the 'Five Day War' is unknown, but most analysts converge on the figure of 35,000-40,000 ground forces provided with air and naval support. They were resisted by about I2,000-15,000 Georgian soldiers. ${ }^{2}$

In order to achieve its military goals, the Russian military strategy envisaged a rapid achievement through a significant advantage in the number of ground troops with support from the air and naval forces. In other words, this strategy was completely built on the model of Soviet military art. As already mentioned, the main military task was to establish control over South Ossetia and Abkhazia, as well as to achieve superiority in the air and at sea. The secondary task, and perhaps equally important, was the elimination of the possibility of receiving military reinforcements by the Georgian side, in particular from the side of foreign armies. This goal was achieved through the blockade of critically important Georgian ports, roads and railroads, as well as by strikes by the air forces of the reserve forces, called in connection with the begin- 
ning of the war, and the Georgian airfields. ${ }^{53}$ An analysis of the Russian troops' actions after reaching the ceasefire agreement indicates that an additional purpose of the Russian army was to neutralize the military potential of Georgia through the destruction or capture of military infrastructure, as well as weapons and equipment.

From this we can conclude that the Russian-Georgian armed conflict of 2008 does not fit the classic canons of hybrid war, mostly because Russia did not try to secretly carry out hostile actions against Georgia, masking them under the actions of local residents. Instead, Russia immediately launched open armed intervention with land, sea and air forces, and also built up its strategy of conducting a Georgian campaign within the framework of an outdated Soviet approach to warfare. Thus, the 'Five Day War' was fundamentally different from the armed conflict in the Crimea and conflict in the East of Ukraine, where Russia focuses on hidden methods of warfare and support of the local population and the destruction of the state from the inside.

\section{Information Component of Hybrid War: Application of Technologies in Georgia and Ukraine}

Information warfare is the key element of modern hybrid war. Operations of information confrontation are a combination of propaganda, misinformation, spread of distorted or false data through diplomatic channels, manipulations through the mass media and the spread of an outright lie aimed at confusing or dividing the opinions of ordinary citizens of the country against which information war is conducted. ${ }^{54}$ Altogether, these actions create a powerful psychological component of the conflict, which helps the aggressorcountry to weaken or even destroy its opponent from the inside. Information confrontation takes place simultaneously on several fronts - inside the society of the state which is attacked, among the citizens of the aggressor country and among the international community.

Today the idea is widespread that the scope of the information / psychological warfare that the Russian Federation is currently carrying out against Ukraine is no lesspowerful than the use of information confrontation during the Cold War. ${ }^{55}$ Russia is able to effectively conduct information warfare because most of the Russian media is controlled and funded by the state, and any criticism of the Russian authorities' actions is persecuted. According to the World Press Freedom Index, in 2016 the Russian Federation ranked I48th out of 166 countries in the 
world rankings freedom of the press..$^{56}$ It is the control of the Russian authorities over the mediathat makes it possible to distribute an official position of the state leadership on an extremely large scale. According to Peter Pomerantsev, 'the new Russia is not only coping with minor CEJISS misinformation, lies, leaks and cyber-sabotageusually associated with 2/20I9 the information warfare. It repeats reality'57.

Application of the political propaganda principles by Russian and pro-Russian media in Ukraine are thoroughly investigated by Jolanta Darczewska. As a consequence, the researcher emphasizes the following principles: (i) mass and long-term influence (the media constantly repeated key anti-Ukrainian slogans and stereotypes: for example, Ukrainian-speaking people were represented as fascists); (ii) the desired information (on the one hand, the media convinced Russian and Russian-speaking users that the Ukrainian authorities prohibited the Russian language; on the other hand, the media promised that Russia would provide assistance and cultural 'salvation'); (iii) emotional agitation (media messages caused emotions and encouraged recipients to act without criticism of the information received); (iv) clarity (the media simplified their messages and divided the world into black and white); (v) hypothetical evidentness (the media linked their messages with political myths: Russian sentiment is equal to patriotism, Ukrainians are equal to fascists, Maidan equals chaos, etc.) $)^{58}$. According to OstapKushnir, Russian media activity in the Crimea is an appropriate illustration of Valery Gerasimov's statements about the role of non-military means in achieving the national interests of Russia ${ }^{59}$.

In parallel with the military operation in Georgia, Russia also conducted information warfare. Unlike Ukraine, the Russian Federation did not try to act secretly or mask its own actions under the 'local self-defence' activities. As already noted, this was an open conventional invasion of the territory of another state, and Russia's information campaign was aimed at creating a pro-Russian-led press coverage of the armed conflict. The purpose of the Russian Federation in the information sphere was to create an image of the victim and not the initiator of the conflict. ${ }^{60}$ Both Russia and Georgia waged information war before, during and after the 2008 conflict, but due to the fact that the two states capabilities of conducting information confrontation were fundamentally different, the Russian side in most cases occupied an attacking position, while the Georgian position was defensive. 
Information warfare techniques in the international media are usually directed at manipulating facts and presenting them in such a way that it allows an aggressor country to distance itself from conflict or create an image of a third-party that conducts a peace-keeping operation. It is so that throughout the entire conflict in Eastern Ukraine, the Russian media has called the events in Donbas a 'civil war'. A similar example of manipulating facts in order to justify their actions during the Russian-Georgian war in 2008 was the situation when the Russian Federation deliberately overestimated the number of losses among civilians through its own media in order to justify its intervention under the pretext of a 'peacekeeping operation'.

In addition, modern war moves slowly from a physical space to cyberspace, and military actions take place simultaneously in both dimensions. Together with the increase of mankind's dependence on computer systems and networks, the awareness is growing that in the future cyberspace will become the next main theatre of operations, and those who benefit in cyberspace will win in physical space too. ${ }^{61}$ Cyberattacks are the key element of the hybrid war, used to disable critically important infrastructure of the enemy, destroy its communication and information flow, as well as acquire important intelligence information about its future actions.

From February 2013, before the Crimean annexation, Russian hacking groups (mainly 'Cyber Berkut') launched a distributed denial of service (known as DDOS attacks) on the main government websites of the ARC, eliminating them or changing their information content. ${ }^{6}$ Somewhat later, such attacks were launched on the Ukrainian telecommunications firm Ukrtelecom ${ }^{63}$, the mass media of Ukraine and NATO countries ${ }^{64}$, the mobile phones of members of the Ukrainian parliament. $^{65}$

The Russian military invasion of Georgia in 2008 also was accompanied by cyberattacks. Along with conventional military actions, pro-Russian hackers paralyzed Georgia's Internet infrastructure, blocking communication during this armed conflict. According to some experts, it was the first time a known cyberattack had coincided with a shooting war. ${ }^{66}$ According to Kenneth Corbin, the goal of Russian cyberattacks was 'isolation and deprivation' of Georgians ${ }^{67}$, as well as isolation of the state from the international community. Event reports and attack listings provided by Russian hackers on websites add credibility to Corbin's theory. Moreover, the Georgian population ex-
Lesia Dorosh

Olha Ivasechko

Jaryna Turchyn 
perienced severe informational and psychological defeat, as it was not able to communicate about current events with the outside world. ${ }^{68}$

Consequently, the Russian military incursions into Georgia and Ukraine were accompanied by cyberattacks aimed at collecting intel-

CEJISS ligence information and isolation of the attacked territories. In both 2/20I9 cases, the DDOS attacks on important Internet resources were carried out in order to disrupt communication and limit the ability of the government to communicate with the local population. This helped the Russian military to successfully carry out military operations. However, unlike Georgia, in addition to communication violations, Russian cyberattacks against Ukraine had a wider goal of destabilizing the internal situation in the country.

In the area of information and psychological influence during the hybrid war in Ukraine, special attention should be paid to the subversion of pro-Russian networks in the region, which contributed to the effectiveness of the hybrid confrontation. It is about the key networks such as Russian intelligence, Russian military bases with their infrastructure, the Russian Orthodox Church, pro-Russian NGOs, Russian media, etc., that created a danger to the statehood and territorial integrity of Ukraine, but were not perceived by the Ukrainian authorities and special services with all due care ${ }^{69}$. According to Ostap Kushnir, during the 25 years of independence, nobody in Kyiv seriously thought about systematic advancement of Ukraine's interests on the peninsula, especially aspects of 'soft power' and pro-Ukrainian networks. Thus, a blurring of the boundary appeared between truth and lies and an alternative reality for those observers who took the view of the Russian mass media on the events was formed and, as a result, the state and non-state institutions weakened, and the undermining of the perception of the legitimacy of the Ukrainian state was diluted. In the opinion of Lada L. Roslycky, using its informal but comprehensive presence on the Crimean Peninsula, the Russian side was able to transfer the attention of indigenous peoples 'from the interests of the state to which they belong to the interests of Russia. ${ }^{\circ}$ It is through the tools of 'soft' (constant cooperation with these networks, the formation of a favourable social and political environment and social mood through the media, the functioning of dual agents, etc.), rather than 'hard' forces, the Russian side quickly succeeded in making the Crimea a subject of the Russian Federation ${ }^{71}$. According to JānisBērziñš, the main objective of the new generation's wars is to reduce the need for deploying hard mil- 
itary power to the required minimum, forcing the enemy, the military and civilian population to support the perpetrator to the detriment of their government and the country ${ }^{72}$.

The Russian Federation used the same methods of information confrontation during the 'Five Day War' against Georgia in 2008 and during the Russian-Ukrainian armed conflict. Russian actions in the information space in both cases were aimed at supporting the Russian armed forces military actions distributing myths, misinformation and manipulation of facts. However, the Russian information campaign against Ukraine was carried out at a qualitatively new level compared to the information confrontation between Russia and Georgia in 2008. Its scale was significantly increased. If in 2008 the Russian Federation gave secondary importance to the information fight and directed it only to justify its actions, in the Russian-Ukrainian conflict the information component of the war has played a no less important role than military actions. Segmentation of the population and incitement of internal conflicts, activation of the local population in support of the military invasion of the Russian armed forces and simultaneously misleading Western states regarding the nature of the conflict contributed to the success of the Russian Federation's military actions on the territory of Ukraine.

\section{Economic Confrontation as an Element of the Hybrid War}

Economic warfare is one of the components of the modern hybrid war. According to George Shambaugh, economic warfare is the use of ether threats or economic influence against another state in order to weaken its economy and to reduce its political and military power. Economic warfare also involves the use of economic means to force the enemy to change its policies or behaviour, the violation of the normal state of its relations with third countries.73 The use of the economic warfare can be extremely influential and destabilizing, especially in those situations where states are dependent on the resources of the aggressor country (especially in the energy sector), which uses hybrid confrontation methods, as we can see in the case of Russia and Ukraine. The Russian Federation has repeatedly launched so-called 'trade wars' against Ukrainian companies and products ('Roshen', as well as the products of a number of meat, dairy and metal companies). ${ }^{74}$

At the same time, Ukraine suffered substantial economic losses as a result of Russian military aggression. As of 2015, production in Ukraine 
has decreased by $7 \%$ since the beginning of the occupation of part of the Luhansk and Donetsk oblasts, a drop in direct foreign investment in Ukraine's economy occurred; the export of Ukrainian goods to Russia, which before the beginning of the conflict was the largest foreign

CEJISS market in Ukraine, decreased by 70\%. In general, in 2014 and 2015, the

$2 / 2019$ Ukrainian economy fell by $16 \% .75$ The economic situation has become complicated not only due to a significant drop in the gross domestic product but also due to the influence of the Russian energy blockade. Prior to the conflict, the Russian Federation was the main supplier of energy resources to Ukraine, which the latter considered necessary to meet the needs of heavy industry and the population. During 20142016 Gazprom periodically returned to the issue of anoutsized rise in gas prices for Ukraine, or a complete halt in the supply of gas during unsatisfactory energy negotiations ${ }^{7}$. Such actions by the Russian side led to a limitation of Ukraine's ability to ensure its own energy security. Lack of energy resources has led to an increase in the vulnerability of the Ukrainian economy, as the lack of access to energy resources destroys the ability of state power to meet the basic needs of its citizens (such as heating in winter), as well as to guarantee the proper functioning of heavy industry. The energy component of Russia's hybrid confrontation with Ukraine and Georgia requires a separate, detailed study.

The Russian Federation repeatedly attempted to exert economic pressure on Georgia. In 1995, the acting president of Georgia, Eduard Shevardnadze, noted the growing activity of the Russian Federation aimed at preventing the construction of the Baku-Tbilisi-Dzheyhan oil pipeline, which would have allowed the transportation of oil from Central Asia, bypassing Russia's territory to European markets. ${ }^{77}$ In September 2004, Moscow blocked all common transport corridors with Georgia, including Russian airspace for Georgian airlines, thus violating a number of international agreements..$^{7}$

During 2006, Moscow actively sought to inflict economic losses on Georgia in response to Georgia's attempts to stop Russia's subversion on the Georgian territory. In addition to energy pressure, Russia also resorted to trade wars. ${ }^{79}$ The Russian Federation initiated a series of prohibitions on the import of Georgian goods, starting with Georgian wines (this product is key to the economy of the country), vegetables and fruits. ${ }^{80}$ Russia used those bans to put pressure on the Georgian government. 
It became possible to restore economic relations between the two states only in $2013 .{ }^{8 \mathrm{r}}$ According to a group of Georgian researchers, the resumption of trade between Georgia and the Russian Federation led to another rise of the Georgian economy'sdependence on the Russian market. According to the research, the resumption of economic ties, along with the spread of the Russian media influence in the Georgian information space, the resumption of work permits for Georgians in Russia, and the current increase of dissatisfaction of Georgian citizens with their authorities, can lead to the use of a hybrid war against Georgia ${ }^{82}$ Consequently, the fact that Russia was able to 'tie' the Georgian economy to its market again is a negative phenomenon as it weakened Georgia's ability to resist hybrid threats. Conversely, economic pressure, at the moment, did not lead to the restoration of the previous state of Ukraine's relations with the Russian Federation (the establishment of the past asymmetric economic partnership with the domination of the Russian side in it). Kyiv has organised alternative ways of economic development of the state, and in this case, powerful economic stress can serve as a powerful impetus for real transformations in the political and economic systems of Ukraine.

Thus, the Russian Federation actively used the dependence of Ukraine and Georgia on its national market in order to exert pressure on these two states and attempts to force their national governments to make decisions that are advantageous for the Russian Federation. For example, economic levers of influence were used by Russia against Ukraine as a 'punishment' for its Euro-Atlantic aspirations, as well as against Georgia in connection with its cooperation with the United States of America.

\section{The Prospect of Further Application of Russian Hybrid Tactics. What Should be Feared by Potential Victims of Russian Pressure?}

Methods of hybrid confrontation were actively used by the Russian Federation during the 'Five Day War' with Georgia in 2008 and the Russian-Ukrainian conflict. The essential difference between these two conflicts is that the Russian-Georgian conflict of 2008 was a conventional war in which non-military means were given a minor role, though some separate elements of the hybrid confrontation were also applied. The Russian Federation used methods of hybrid confrontation not to destabilize the internal situation in Georgia, but to legiti-
Lesia Dorosh

Olha Ivasechko Jaryna Turchyn 
mize its own aggressive actions. Unlike the 'Five Day War', a full hybrid war was held in the Crimea in 20I4. So, the beginning of the war was not announced, all operations were carried out secretly, and the official Moscow distanced itself from all the events on the peninsula.

CEJISS It is necessary to obtain a number of certain necessary conditions 2/20I9 in order to conduct a hybrid war aimed at achieving certain political goals. Only their proper configuration creates favourable circumstances for the deployment of a hybrid confrontation. Today's empirical evidence suggests that at least the following basic conditions are required to successfully carry out the hybrid warfare:

I. the state against which the hybrid war is carried out has incompetent leadership and does not fulfil its basic functionsfor a long period of time;

2. the population of this state is divided;

3. the population of the state has certain sympathies for the aggressor country and is exposed to the soft power tools of the latter;

4. the defending country has a common border with the aggressor country and cannot exercise effective control over its state borders;

5. the country being attacked does not have reliable allies;

6 . the aggressor country has a certain level of prestige in the international community, which allows it to successfully distribute its version of events. ${ }^{83}$

Despite the tremendous success of the hybrid war in the Crimea, this approach is unlikely to be widespread. The conditions for the conflict were unique, or at least extremely rare, and they can hardly be reproduced in any other place. At the time of the beginning of the hybrid war, there was a naval base of the Russian navy with a large military contingent in the Crimea, the majority of the local population in the region had a low level of self-identification with Ukraine and sympathized with the authorities of the Russian Federation (including local Crimean politicians and high-ranking military personnel), the local parliament was loyal to Russia, and the Russian mass media dominated in the informational space of the Crimea.

What worked in the Crimea quickly failed in Eastern Ukraine, where Vladimir Putin probably made a fundamental mistake relying on the support of the local population and Russian-speaking Ukrainians in general. The Kremlin failed to achieve quick and cheap accession of new regions to Russia, the creation of quasi-independent, un- 
recognized regions under the Russian protectorate such as, for example, Abkhazia and South Ossetia, or to reach an agreement that would establish Russia's long-term influence in Ukraine. ${ }^{84} \mathrm{Ukraine}$ eventually found ways to withstand such hybrid influences, and Russia had to launch an open intervention of conventional forces in the summer of 2014 in order to prevent the defeat of its irregular forces.

In view of the fact that the combination of conditions necessary for a successful hybrid war conductis difficult to achieve, we believe that hybrid warfare will become more of a situational phenomenon, becausehostilities against other states without necessary conditions will lead either to a quick defeat of the aggressor state, or willrequire aswitch to conventional warfare that requires significant financial costs and will inevitably lead to the decline in its prestige among the international community. Eventually, Mark Galeotti, who is credited with starting the use of the term 'doctrine of Gerasimov', claims that it's time to forget about it. The arguments of the analyst are that it does not have a single organizational principle, not to mention the controlling authority. There is a broad political goal - to distract, divide and demoralize, but, in the rest, it is largely opportunistic, fragmentary, and even sometimes contradictory. ${ }^{85}$ For example, according to the Wilson Center analysis, Russia's actions in Ukraine were not part of a coherent long-distance strategy, but rather reflected '... an unplanned sequence of varied tools to match different, often unexpected, operational realities' ${ }^{86}$

Certainly, single hybrid tactics against the enemy state can be applied without bringing in a full-scale hybrid war.For example, the use of economic levers of influence, such as the introduction of restrictions on the import of goods to weaken the economy of the enemy, allows it to change the behaviour and make disadvantageous decisions without the deployment of military actions.Information campaigns aimed at undermining the legitimacy of the national government of the enemy country as well asthe destruction of inner harmony can be initiated during peacetime. Cyberattacks, which due to infiltration of information technologies into all spheres of human life, can cause significant damage to the enemy. They can also be used in peacetime since it is impossible to prove the involvement of the aggressor's stategovernment in such attacks.

Nevertheless, the Central European statesshould pay special attention to Russia.Fighting against an opponent who carries out hybrid war is a task for the whole society and should be conducted
Hybrid Tactics of the Russian Federation 
in different spheres.In our opinion, a much more dangerous form of Russian aggression, above all, against the NATO states, will be the deployment of a full-blown conventional war, especially with the threats of using the nuclear weapons. NATO's states have already be-

CEJISS gun to capture the experience of Ukrainian soldiers regarding Russian

2/20I9 tactics and technologies. ${ }^{87}$ However, only a tactical improvement in the hybrid confrontation is not enough to provide a permanent deterrent against a traditional armed attack.

Lesia Dorosh is affiliated to the Department of Political Science and International Relation of Lviv Polytechnic National University, Lviv (Ukraine) and may be reached at lesia.o.dorosh@lpnu.ua.

Olha Ivasechro is affiliated to the Department of Political Science and International Relation of Lviv Polytechnic National University, Lviv (Ukraine) and may be reached at ivasechko.20II@ukr.net.

Jaryna Turchyn is affiliated to the Department of Political Science and International Relation of Lviv Polytechnic National University, Lviv (Ukraine) and may be reached at turchynj@ukr.net.

\section{Notes}

I Ostap Kushnir (20I7), 'Russian geopolitical advancements in the Black Sea region: the annexation of Crimea', Athenaeum. Polish Political Science Studies, vol.56/20I7, pp.III-I35, available at:<https://www.academia. edu/35935280/Russian_Geopolitical_Advancements_in_the_Black_Sea_ Region_The_Annexation_of_Crimea $>$ (accessed 20 January, 20I9).

2 Zbigniew Brzezinski(20I4).'Confronting Russian Chauvinism', The American Interest, available at:<http://www.the-american-interest.com/ articles/20I4/06/27/confronting-russian-chauvinism> (accessed 20 January, 2019).

3 Ostap Kushnir(20I6), 'Ukrainian Policies in the Black Sea Littoral: History, Current Trends and Perspectives', Journal of Contemporary European Studies, 25(2), pp.I63-I79, available at:<http://www.tandfonline.com/doi/ abs/Io.Io80/I4782804.20I6.I2 I9845?journalCode=cjea20 $>\quad$ (accessed 2 January, 2019).

4 Ostap Kushnir (20I7).

5 Rod Thornton (2015), 'The Changing Nature of Modern Warfare, RUSI Journal, I6o, 4, pp.40- 48 . 
6 Ralph D. Thiele (2015),'Crisis in Ukraine - The Emergence of Hybrid Warfare', ISPSW Strategy Series, May, available at:< https://www.files.ethz. ch/isn/I90792/347_Thiele_RINSA.pdf > (accessed 2 January, 20I9).

7 Robert Coalson (2014), ‘Top Russian General Lays Bare Putin's Plan for Ukraine',The Huffington Post,available at: <http://www.huffingtonpost. com/robert-coalson/valerygerasimov-putin-ukraine_b_574848o.html> (accessed 2 November, 2017).

8 Stephen M. Dayspring (2015),Toward a Theory of Hybrid Warfare: the Russian Conduct of War During Peace, Monterey, p. 2oI,available at: <https://www. hsdl.org/?view\&did=790442> (accessed 3I October, 20I7).

9 Mark Galeotti (20I4), 'The 'Gerasimov Doctrine' and Russian NonLinearWar', MILITARY - RUSSIA,SECURITY,UKRAINE, available at:<https:// inmoscowsshadows.wordpress.com/20I4/07/o6/the-gerasimov-doctrineand-russian-non-linear-war/> (accessed 20 January, 2019).

Io James K. Wither (2016), 'Making Sense of Hybrid Warfare', Connections, Vol. I5, No. 2, pp. 73-87, available at:<https://www.jstor.org/ stable/2632644I?seq=I\#metadata_info_tab_contents $>$ (accessed I2 January, 2019).

II Mark Landler and Michael R. Gordon (2014), 'NATO Chief Warns of Duplicity by Putin on Ukraine', The New York Times, July available at:< http://www.nytimes.com/2014/o7/o9/world/europe/nato-chief-warns-ofduplicity-by-putin-on-ukraine.html?_r=I(accessed I5 January, 20I9).

I2 James K. Wither (20I6),Stephen M. Dayspring (2015).

I3 Peter R. Mansoor (2012), 'Hybrid Warfare in History', in Williamson Murray and Peter R. Mansoor (eds.) Hybrid Warfare: Fighting Complex Opponents from the Ancient World to the Present, New York: Cambridge University Press, p. I-I7.

I4 James K. Wither (2016).

I5 Elie Tanenbaum (2015), 'Hybride warfare in the strategic spectrum: An Historical assessment', in Guillaume Lasconjarias and Jeffrey A.Larsen (Eds.) NATO's response to Hibride Threats, available at: < https://www.files. ethz.ch/isn/I95405/fp_24.pdf $>$ (accessed 26 January, 20I9).

I6 Peter R. Mansoor (20I2), p. I-I7.

I7 Operational Environments to 2028: The Strategic Environment for Unified Land Operations (2016), United States Army Training and Doctrine Command, p. 5, available at: < http://www.arcic.army.mil/app_Documents/TRADOC_ Paper_Operational-Environments-to-2028-Strategic-Environment-forUnified-Land-Operations_AUG20I2.pdf > (accessed I8 April, 20I7).

I8 Joseph Schroefl and Stuart Kaufman (20I4), 'Hybrid Actors, Tactical Variety: Rethinking Asymmetric and Hybrid War', Studies in Conflict \& Terrorism, 37:10, p. 867.

I9 Stephen M. Dayspring (2015).

20 Timothy McCulloh and Richard Johnson (2013), Hybrid Warfare, JSOU Report, August, pp. 13-4; Nathan P. Freier (2007), Strategic Competition and Resistance in the 2Ist Century: Irregular, Catastrophic, Traditional, and Hybrid Challenges in Context, Carlisle Barracks, PA: Strategic Studies Institute, U.S. Army War College.

2I Jack McCuen (20II), 'Strategy of Hybrid War,' in Paul Brister, William H. Natter and Robert R. Tomes (eds.),Hybrid Warfare and Transnational Threats: Perspectives for an Era of Persistent Conflict, New York, NY: Council for Emerging National Security Affairs, pp. 70-82.
Lesia Dorosh

Olha Ivasechko

Jaryna Turchyn 
22 Douglas Lovelace (2016), Hybrid Warfare and the Gray Zone Threat, Oxford University Press, p.64.

23 Thomas Bjerregaard (2012), Hybrid Warfare: a Military Revolution or Revolution in military affairs?, Fort Leavenworth, p.I2.

24 Hoffman Frank G. Hoffman (2009),'Hybrid Warfare and Challenges', Small Wars Journal, №52, pp. 34-39.

CEJISS

25 Peter Pomerantsevand Michael Weiss (20I4), 'The Menace of Unreality: How the Kremlin Weaponizes Information, Culture and More: Special Report,The Interpreter, New York, p.44,available at: < http://www. interpretermag.com/wp-content/uploads/20I4/II/The_Menace_of_ Unreality_Final.pdf $>$ (accessed I February, 20I7).

26 Keir Giles (2015), 'Russia and ItsNeighbours:Old Attitudes,New Capabilities'inKenneth Geers(Ed.), CyberWarinPerspective:RussianAggression againstUkraine, NATOCCDCOEPublications, Tallinn, availableat: $<$ https:// ccdcoe.org/sites/default/files/multimedia/pdf/CyberWarinPerspective_ Giles_02.pdf $>$ (accessed I February, 20I7).

27 David M. Hollis (2011), 'Cyberwar Case Study: Georgia 2008', Small Wars Journal,available at: <http://smallwarsjournal.com/jrnl/art/cyberwar-casestudy-georgia-2008> (accessed 4 February, 2017).

28 Zdeněk Kříž, Peter Števkov, Zinaida Shevchuk (2015),Hybrid Warfare: A New Phenomenon in Europe's Security Environment, Prague: Jagello 2000, p. I6.

29 Zdeněk Kř́žz, Peter Stevkov, Zinaida Shevchuk (2015), p. II.

30 Yana Humen (20I7), 'Five Principles of Media Propaganda and Russian GeopoliticalExpansionism', Dialog. Media studios, Issue 23, pp. 53-69.

3I Taras Kuzio (2015), 'The Origins of Peace, Non-Violence, and Conflict in Ukraine' in Agnieszka Pikulicka-Wilczewska \& Richard Sakwa (Ed.) Ukraine and Russia:People, Politics,Propaganda andPerspectives, available at:<http:// www.e-ir.info/wp-content/uploads/2015/03/Ukraine-and-Russia-E-IR.pdf $>$ (accessed 20 January, 2019).

32 Marcel H. Van Herpen (20I4), WojnyPutina. Czeczcnia, Gruzjia, Ukraina 20I4, Warszawa, Proszynski i S-ka, p.402.

33 Evan Osnos,David Remnick, andJoshua Yaffa (2017), 'Trump, Putin, and the New Cold War.What lay behind Russia's interference in the 2016 election and what lies ahead?', The New Yorker, March 6, available at:<https://www. newyorker.com/magazine/2017/03/06/trump-putin-and-the-new-coldwar> (accessed 20 January, 2019).

34 Jolanta Darczewska (2016),Russia's armed forceson the information war front. Strategic documents, available at:<https:/www.osw.waw.pl/sites/default/ files/prace_57_ang_russias_armed_forces_net.pdf> (accessed 2 January, 2019), Jolanta Darczewska (2015), The devil is in the details. Information warfare in the lightof Russia 's military doctrine, available at:<https://www.osw.waw.pl/ sites/default/files/pw_50_ang_the-devil-is-in_net.pdf $>$ (accessed 2 January, 20I9), Jolanta Darczewska (2014), The Anatomy of Russian Information Warfare: the The CrimeanOperation, a Case Study', Point of View, No. 42.

35 Володимир Горбулін (2015), 'Чорна діра': нескінченний тупик урегулювання', Дзеркало тижня, availableat: <http://gazeta.dt.ua/ internal/chorna-diraneskinchenniy-tupik-uregulyuvannya-_.html> (accessed 28 August, 2017).

36 Володимир Горбулін (2ог6), 'Гібридна війна: все тільки починається...', Дзеркало тижня, available at: <http:/gazeta.dt.ua/internal/gibridnaviyna-vse-tilki-pochinayetsya-_.html $>$ (accessed 25 March, 20I7). 
37 Iulianna Romanchyshyna (2015),'Hybrid Wars in Post-Soviet Spaces as a Challenge to the West',Humanity in Action, available at: <http://www. humanityinaction.org/knowledgebase/703-hybrid-wars-in-post-sovietspaces-as-a-challenge-to-the-west $>$ (accessed in February, 20I7).

38 П. І. Шевчук (2014), 'Інформаційно-психологічна війна Росії проти України: як ій протидіяти', Демократичне врядування, Вип. I3, availableat: <http://nbuv.gov.ua/UJRN/DeVr_2OI4_I3_II> (accessed 25 September, 20I7).

39 Євген Магда (2015),Гібридна війна: вижити і перемогти, Х.: Віват, с. 304.

40 'Complex Crises Call for Adaptable and Durable Capabilities' (2015), The Military Balance, II5, I, p. 5.

4I Ralph D. Thiele (2015).

42 Mark Galeotti (20I4).

43 Vitalii Usenko (2015), 'Russian hybrid warfare: what are effectsbased network operations and how to counteract them', EuroMaidan Press,available at: <http://euromaidanpress.com/2015/or/I7/russianhybrid-warfare-what-are-effectbased-network-operations-and-how-tocounteract-them $>$ (accessed I7 January, 20I7).

44 Валерий Герасимов (2013), 'Ценность науки в предвидении', Военнопромышленный курьер, № 8 (476).

45 Michael Weiss, James Miller, Pierre Vaux, Catherine A. Fitzpatrick (2015), 'An Invasion by Any Other Name: The Kremlin's Dirty War in Ukraine', The Interpreter, New York, p.84, available at: < http://www.interpretermag. com/wp-content/uploads/2015/o9/IMR_Invasion_By_Any_Other_Name. pdf $>$ (accessed I5 February, 20I7).

46 András Rácz (2015),Russia’s Hybrid War in Ukraine: Report, Helsinki: The Finnish Institute of International Affairs, p. Ior.

47 Igor Sutyagin (2015), 'Russian Forces in Ukraine: Briefing Paper', Royal United Services Institute for Defence and Security Studies,p.I, available at: <https://rusi.org/sites/default/files/201503_bp_russian_forces_in_ ukraine.pdf $>$ (accessed 5 March, 20I7).

48 Igor Sutyagin (2015), p.4.

49 Igor Sutyagin (2015), p. 2.

50 Michael Weiss, James Miller, Pierre Vaux, Catherine A. Fitzpatrick (2015).

$5 \mathrm{I}$ В. Шлыков (2008), 'Война с неизвестной целью',Россия в глобальной политике, http://www.globalaffairs.ru/number/n_ıI628> (accessed 3 October, 20I7).

52 Ariel Cohen, Robert E. Hamilton (2011),The Russian Military and the Georgia War: Lessons and Implications,p. II-I2, available at: <http://www. strategicstudiesinstitute.army.mil/pdffiles/pubio69.pdf> (accessed 26 February, 20I7).

53 Carolina Vendil Pallin, Fredrik Westerlund (2009), 'Russia's war in Georgia: lessons and consequences', Small Wars \& Insurgencies, Vol. 20, №2, p. 403.

54 Richard Weitz (20I4), 'Countering Russia's Hybrid Threats',Diplomaatia,available at: <https://www.diplomaatia.ee/en/ article/countering-russias-hybrid-threats/> (accessed 5 November, 2017).

55 Armand Gosu, Octavian Manea (2015),'The Russian psychological warfare', Black Sea in Access Denial Age, available at: <http://www.roec.biz/bsad/ portfolio-item/the-russianpsychological-warfare> (accessed II September, 20I6). 
56 '2016 World Press Freedom Index' (2016), Reporters Without Borders, available at: <https://rsf.org/en/ranking > (accessed 5 February, 20I6).

57 Peter Pomerantsev (2015), 'How Russia is Revolutionizing Information Warfare', Defense One, September 9, available at:<http://www.defenseone. $\mathrm{com} /$ threats/2014/o9/how-russia-revolutionizing-information-

CEJISS warfare/93635/> (accessed 29 January, 20I9).

2/20I9 58 Jolanta Darczewska (2014).

59 Ostap Kushnir (20I7).

6o Carolina Vendil Pallin, Fredrik Westerlund (2009), p. 404.

6I Noam Ben-Asher, Cleotilde Gonzalez (2015), 'CyberWar Game: A Paradigm for Understanding New Challenges of Cyber War', Advances in Information Security, Vol. 56, p. 207-220.

62 Tim Maurer, Scott Janz (2014), 'The Russia-Ukraine conflict: Cyber and information warfare in a regional context', EU Reporter,available at: $<$ https://www.eureporter.co/frontpage/20I4/Io/I8/the-russia-ukraineconflictcyber-and-information-warfare-in-a-regional-context> (accessed I8 October, 20I7).

63 'Ukrtelecom's the Crimean sub-branches officially report that unknown people have seized several telecommunications nodes in the the Crimea' (20I4), Ukrtelecom,available at: <http://en.ukrtelecom.ua/about/ news?id=I20467> (accessed 28 February, 20I6).

64 Mathew Schwartz (20I4), 'DDoS Attacks Hit NATO, Ukrainian Media Outlets', Dark Reading,available at: <http://www.darkreading.com/ attacks-and-breaches/ddosattacks-hit-nato-ukrainian-media-outlets/d/did/II27742> (accessed I7 March, 20I7).

65 Pavel Polityuk, Jim Finkle (2014), 'Says communications hit, MPs phones blocked', Reuters, available at: <http://in.reuters.com/article/ukrainecrisis-cybersecurityidINL6NoMi2CF2OI40304> (accessed 4 March, 20I7).

66 David M. Hollis (20II), 'Cyberwar Case Study: Georgia 2008', Small Wars Journal,available at: <http://smallwarsjournal.com/jrnl/art/cyberwar-casestudy-georgia-2008 (accessed I2 February, 2017).

67 Kenneth Corbin (2009), 'Lessons From the Russia-Georgia Cyberwar', Internet News, available at: <http://www.internetnews.com/government/ article.php/38IooII/Lessons+From+the+RussiaGeorgia+Cyberwar.htm> (accessed 2 March, 20I9).

68 Paulo Shakarian, Jana Shakarian, Andrew Ruef (2013),Introduction to cyberwarfare: A Multidisciplinary Approach, Waltham: Elsevier, p.26.

69 Ostap Kushnir (20I7).

70 Lada L. Roslycky (20II), 'Russia's smart power in Crimea: sowing the seeds of trust', Southeast European and Black Sea Studies, Vol. II, Issue 3: Managing Distrust in the wider Black Sea Region, pp. 299-3i6.

7 I Ostap Kushnir (20I7).

72 Jānis Bērziņš (20I4), 'Russian New Generation Warfare in Ukraine: Implications for Latvian Defense Policy', National Defence Academy of Latvia, Center for Security and Strategic Research, Policy Paper, No. 2, available at:< https://sldinfo.com/wp-content/uploads/20I4/05/New-GenerationWarfare.pdf $>$ (accessed 2 January, 2019).

73 George Shambaugh (2007), 'Economic warfare', Encyclopedia Britannica, available at: <https://www.britannica.com/topic/economic-warfare> (accessed I7 June, 2017).

74 Зіновія Воронович (2013), 'Росія оголосила Україні війну. Торговельну. 
По всіх 'фронтах', Високий Замок, available at: <http://wz.lviv.ua/ ukraine/I23760-rosiiaoholosyla-ukraini-viinu-torhovelnu-po-vsikhfrontakh $>$ (accessed I4 August, 20I7).

75 Anders Aslund (2015),'Russia's War on Ukraine's Economy', The Japan Times,available at: <http://www.japantimes.co.jp/opinion/2015/07/I3/ commentary/worldcommentary/russias-war-on-ukraines-economy/\#. WFmsAhGg-It $>$ (accessed in June, 20I7).

76 'Russia halts gas supplies to Ukraine after talks breakdown'(2015), BBC News, available at:<http://www.bbc.com/news/world-europe-3334I322/> (accessed io January, 2019).

77 Thornike Gordadze (2009),'Georgian-Russia Relations in the I990s', The Guns of August 2008, p. 39.

78 Ana K.Neidermeier (2008), Countdown to War in Georgia: Russia's Foreign Policy and Media Coverage of the Conflict in South Ossetia and Abkhazia, Minneapolis: East View Press, p. 579.

79 Stephen M. Dayspring (2015), p. 92.

80 Iulianna Romanchyshyna (2015).

8I Вікторія Матола (2013), 'Росія зводить свою зовнішню політику до торговельних війн з сусідами', Тиждень.ua, availableat: <http://tyzhden. ua/News/89I04> (accessed I2 September, 20I7).

82 G. Mgaloblishvili, M. Kutelia, I. Guruli, N. Evgenidze (20I6), Hybrid Warfare and the Changing Security Landscape In the Euro-Atlantic Area: Political and Economic Implications, Tbilisi: Economic Policy Research Center, pp.I8-2I.

83 Zdeněk Kříž, Peter Števkov, Zinaida Shevchuk (2015), p. I2.

84 Paul J. Saunders (2015),'Why America Can't Stop Russia's Hybrid Warfare',The National Interest,available at: <http://nationalinterest.org/ feature/why-america-cant-stop-russiashybrid-warfare-I3I66?page=show $>$ (accessed 26 June, 20I6).

85 Mark Galeotti (20I8), 'I'm Sorry for Creating the "Gerasimov Doctrine", Foreign policy, available at:<https:/foreignpolicy.com/2018/03/05/imsorry-for-creating-the-gerasimov-doctrine/ > (accessed 20 January, 20I9).

86 Michael Kofman and Matthew Rojansky (2015), 'A Closer Look at Russia's Hybrid War', Wilson Center, Kennan Cable, No. 7, April I4, available at:< https://www.wilsoncenter.org/sites/default/files/7-KENNAN\%20CABLEROJANSKY\%2oKOFMAN.pdf $>$ (accessed 2 January, 20I9).

87 Paul McLeary and Adam Rawnsley (2015), 'Situation Report', Foreign Policy,available at:< http://foreignpolicy.com/2015/12/ro/situation-reportcarter-gets-through-another-hill-appearance-new-book-by-formerintel-chief-nato-training-against-russian-tactics-india-comes-to-thepentagon-house-wants-to-supply-kurds-new-nort/> (accessed I5 January, 2019).
Lesia Dorosh

Olha Ivasechko

Jaryna Turchyn 